\title{
The Incremental Usefulness Of Income Tax Allocations In Predicting One-Year-Ahead Future Cash Flows
}

Benjamin P. Foster, (E-mail: ben.foster@louisville.edu), University of Louisville Terry J. Ward, (E-mail: tward@mtsu.edu), Middle Tennessee State University

\begin{abstract}
SYNOPSIS
Interperiod income tax allocation has been a hotly debated financial accounting issue for a long time. Critics of interperiod tax allocation frequently question the usefulness of the extra information, particularly considering the FASB's decision usefulness approach stated in its Conceptual Framework. This study extends the research of Cheung et al. (1997) and Krishnan and Largay (2000) by using the ability to predict future taxes paid and future cash flow as criteria to evaluate the usefulness of interperiod tax allocation. This study extends previous research by examining not only whether interperiod tax allocation included in financial statements is useful, but also by examining whether such information is incrementally useful beyond taxes paid. For predicting future taxes paid and operating cash flow, our analyses provides little evidence that interperiod tax allocation information included in financial statements adds incremental predictive value beyond taxes paid as reported on the cash flow statement.
\end{abstract}

\section{INTRODUCTION}

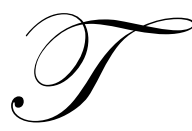

he decision usefulness approach to evaluating accounting information provides the justification for examining the usefulness of reported interperiod tax allocations. Cash flow literature suggests that cash taxes paid may furnish more useful information to financial statement users than traditional, fullyallocated income tax expense. (See, for example, Lee 1972, 27; Heath 1978, 20; and Ward 1995, 30.) Also, the American Accounting Association (AAA) (1977) discussed the fact that allocations in financial accounting are hard to reconcile with much accounting theory.

Thomas $(1969,1974$, and 1975) questioned the value of accounting allocations to financial statement users by asserting that any allocation method chosen is arbitrary and, consequently, allocations do not assist in, and may even impair, decision making. He also claimed that allocations do not represent economic reality particularly when applied over time like interperiod tax allocation.

[C]ontemporary tax allocation practices embody the allocation problem in one of its most pathological forms: an incorrigible allocation is based on the differences between second and third arbitrary allocations--nonsense cubed, as it were (Thomas1974, 120).

Consequently, previous literature provides a basis for examining the usefulness of tax paid and deferred tax measures as variables in predictive models. Also, Statement of Accounting Standards (SFAS) No. 95's (Financial Accounting Standards Board (FASB) 1987a) requirement of disclosure of cash taxes paid on the cash flow statement facilitates study of the usefulness of cash taxes paid.

Using actual cash flow information and cash flow predictive models, we tested the tax information reported in the financial statements provides any incremental useful value beyond taxes paid when predicting taxes paid or operating cash 
flows one year in advance. The next section more fully discusses the motivation for our study. Following sections discuss prior research, our research methods, and the results of our analyses. The paper ends with a discussion of conclusions drawn from the study and suggestions for further research.

\section{MOTIVATION FOR STUDY}

The Financial Accounting Standards Board's (FASB) Statements of Financial Accounting Concepts serve as a framework for developing accounting standards. Concept Statement No. 1 (FASB 1978) emphasizes the usefulness of information provided to users of financial statement information, particularly information helpful in assessing the amount and timing of future cash flows to investors, creditors, and the enterprises themselves. Concept No. 2 (FASB 1980), noted that information must be understandable and have predictive value or feedback value to users.predictive ability of fully allocated income tax expense as required on current income statements. We found little evidence to indicate that deferred

Cash flow advocates (e.g., Ward 1995, 30; Lee 1972, 27) have asserted that cash flow information provides useful information to financial statement users. For example, Ward $(1995,30-35)$ and Heath $(1978,20)$ link cash flows to solvency or insolvency of firms. They state that a firm must maintain flexibility and stability in its cash flows to remain healthy. Cash flow literature suggests that using interperiod allocations in calculating income tax expense may be misleading because actual taxes paid may differ substantially from the amount due for the period (Lee 1972, 27-31). Likewise, Thomas (1969, 1974, and 1975) asserted that interperiod income tax allocation may impair financial statement users' decision making. Consequently, previous literature suggests that allocated income tax expense may not provide information useful to lenders, investors, managers, and society beyond cash paid during the period for income taxes.

Examining the usefulness of the cash basis approach to income tax reporting investigates the appropriateness of SFAS No. 95 (FASB 1987a, paragraph 121) requirements for reporting income taxes paid on the Statement of Cash Flows. The FASB (1987a, paragraph 106) considered two approaches to reporting cash flows from operations, the direct and indirect methods. The direct method reports gross cash inflows from sales and gross cash outflows for operating expenses, including income taxes. The indirect method adjusts reported net income for non-cash revenues, expenses that do not require a cash outlay, changes in current assets and current liabilities (including changes in taxes payable), and items included in net income arising from other activities. If the indirect method is used, the firm must disclose the amount of interest and income taxes paid.

\section{Hypotheses And Implications}

Under the decision usefulness criterion, fully allocated income tax should be useful beyond cash tax paid to require deferred tax reporting. Evidence indicating that deferred tax information is incrementally useful beyond taxes paid would support current GAAP and suggest continued reporting of fully allocated income tax expense measures in the financial statements. Finding no incremental usefulness would provide evidence that fully allocated income tax expense as currently reported may not meet the decision usefulness criteria.

$\mathbf{H}_{1}$ : Deferred tax measures do not add predictive ability to one-year-ahead taxes paid prediction models that include a taxes paid measure.

$\mathbf{H}_{2}$ : Deferred tax measures do not add predictive ability to one-year-ahead operating cash flow prediction models that include a taxes paid measure.

\section{PRIOR RESEARCH}

Financial distress research tested the usefulness of income tax measures in explaining future financial distress. Aziz and Lawson $(1989,59)$ found that the taxes paid cash flow component was significant each year when examined in a cashflow-based bankruptcy prediction model. Ward and Foster $(1996,137)$ tested Thomas's theory by examining the impact of large 
accounting allocations on the usefulness of accounting information to predict financial distress. Ward and Foster (1996, 144145) found evidence that models including operating flow measures that eliminated depreciation and deferred taxes more accurately predicted financial distress than did models including a net income measure. This finding suggests that allocations lessened the ability of reported net income to predict distress.

Subsequent studies have examined the ability of different information to assist in predicting future cash flows. Krishnan and Largay (2000) examined the ability of items related to cash flow from operations reported under the direct and indirect methods to predict future cash flows. They included several variables in different models. In one model, Krishnan and Largay $(2000,226)$ found that the deferred tax balance was significant for some years studied. In another model, they found that a taxes paid variable was significant for some years studied. Cheung et al. (1997) examined whether deferred tax information helps predict future cash flows. They found that both the deferred tax expense and change in the deferred tax balance sheet amount added significantly to models predicting future income taxes paid and future operating cash flows.

However, neither Krishnan and Largay (2000) nor Cheung et al. (1997) included taxes paid and any other tax variable in the same operating cash flow predictive model. They did not test whether deferred taxes provided incremental useful information above taxes paid. Also, Krishnan and Largay (2000, 223) used data from 1988 to 1993 while Cheung et al. (1997, 9) analyzed data from 1977 to 1994 . SFAS No. 109 (FASB 1992) was not fully implemented by some companies until fiscal years beginning after December 15, 1992. Thus, part of their developmental period and predictive period included a time in which companies may have been reporting a transition from the old APB No. 11 (APB 1967) deferred tax method to the new SFAS No. 109 (FASB 1992) method of interperiod tax allocation.

To examine whether deferred tax disclosures were useful in predicting future operating cash flows, Legoria and Sellers (2005) painstakingly examined 1994 annual reports to obtain companies' deferred tax assets, valuation allowance, and deferred tax liabilities. Consequently, their sample was limited to only 1994 for independent variables and included 1,642 companies. They found that the deferred tax disclosures were useful in predicting future operating cash flow (the dependent variable). Legoria and Sellers' (2005) model included only 1994 data for sales, as a proxy for size, and operating cash flow as control variables.

\section{Extensions Of Prior Research}

Like Cheung et al. (1997), Krishnan and Largay (2000), and Legoria and Sellers (2005), we use the ability to predict future cash flows as criteria to evaluate the incremental usefulness of deferred tax information. This paper extends their research to directly test the incremental usefulness of deferred tax items reported in the financial statements by including income taxes paid in a model to predict one-year-ahead operating cash flow. The information on income taxes paid would be readily available without deferred tax calculations and would be easier for users to understand.

Unlike Cheung et al. (1997) and Krishnan and Largay (2000), but like Legoria and Sellers (2005), this study more directly examines the usefulness of current interperiod tax allocation standards by examining data from a time period in which the current standards were fully implemented. While Legoria and Sellers' (2005) sample was limited to 1,642 companies that had adequate information from 1994 to construct their variables, we work with a much larger sample with data taken from several years. Unlike Legoria and Sellers (2005), we scale our variables following the methods of Cheung et al. (1997) and included several control variables in our operating cash flow prediction models.

In our initial analysis, we used the mean absolute percentage error (MAPE) and Friedman's S statistic as did Cheung et al. (1997) and Krishnan and Largay (2000). This analysis produced inconsistent and contradictory results. In many cases, when significant variables were added to models the MAPE declined, and when insignificant variables were added, the MAPE rose. Consequently, we use a more powerful statistical technique, the Vuong statistic (Vuong 1989), than those studies to compare the predictive ability of models including the different income tax variables. 


\section{METHODS}

\section{Sample Selection}

We conducted analyses with cross sectional regression models similar to those used by Cheung, et al. (1997), which were based on models developed by Lorek and Willinger (1996). We chose to use years 1994 to 2000 to test the predictive ability of the income tax variables. For each of these years we obtained the predictive variables from the prior year. Thus, our first year's data comes from 1993. We chose to limit our analysis to years after 1992 to avoid years in which companies reported income tax expense under APB No. 11 or may have been transitioning from APB No. 11 to the new SFAS No. 96 (FASB 1987b) and SFAS No. 109 (FASB 1992) rules.

We selected companies from Research Insight Compustat Research and Active Files that had data necessary to conduct the analysis. Following Barth et al. (2001, p. 37) we only included companies with sales > \$10 million. Our sample includes 31,620 observations (32,173 observations for the TAXPD predictive models that require fewer variables). (The Appendix provides a summary breakdown of the sample by industry and by year for the sample.) Also, to consider firms for which investors might find deferred tax information most useful, we conducted additional analyses like Cheung et al. (1997) with a sample of companies whose deferred tax liability was equal to or greater than 1 percent of their total assets $(13,043$ observations). Further analyses were conducted on samples that included only positive and negative deferred tax liability changes, respectively.

\section{Variables}

Like Cheung et al. (1997), we used future taxes paid $\left(\mathrm{TAXPD}_{\mathrm{t}+1}\right)$ as one dependent variable. Our analysis differs from Cheung et al. (1997) in that we use actual taxes paid while they estimated taxes paid as reported income tax expense less deferred tax expense plus income taxes payable at the beginning of the year less income tax payable at the end of the year (Cheung et al. 1997, 4). As independent variables of interest, our study examined the predictive usefulness of taxes paid $\left(\mathrm{TAXPD}_{\mathrm{t}}\right)$ and the same deferred tax expense measures $\left(\mathrm{DEF}_{\mathrm{t}}\right.$, and DEF2 $\mathrm{t}$ ) used by Cheung et al. $(1997,4)$.

$\begin{array}{lll}\mathrm{TAXPD}_{\mathrm{t}} & = & \text { taxes paid during year } \\ \mathrm{DEF}_{\mathrm{t}} & = & \text { deferred tax expense at time } \mathrm{t}, \\ \mathrm{DEF} 2_{\mathrm{t}} & = & \text { change in the deferred tax liability from the balance sheet at time } \mathrm{t} .\end{array}$

DEF1 includes changes in both current and noncurrent deferred tax liabilities. DEF2 only contains changes in noncurrent deferred tax liabilities.

Unlike Legoria and Sellers (2005), our large sample of companies over several years prevented us from examining each annual report to obtain companies' deferred tax assets, valuation allowance, and deferred tax liabilities. However, to further examine the usefulness of deferred tax information, we used future operating cash flows $\left(\mathrm{CFFO}_{\mathrm{t}+1}\right)$ as a dependent variable like Legoria and Sellers (2005) and Cheung et al. (1997). To determine whether or not deferred tax measures reported in the financial statements are useful in predicting future operating cash flow, we added $D E F 1_{t}$, and $D E F 2_{t}$ to the base model used by Cheung et al. (1997, p. 8). The base model includes the following independent variables:

$\begin{array}{lll}\mathrm{CFFO}_{\mathrm{t}} & = & \text { cash flow from operating activities during year } \\ \mathrm{OIBDP}_{\mathrm{t}} & = & \text { operating income before depreciation during year } \\ \mathrm{AR}_{\mathrm{t}} & = & \text { accounts receivable at time, } \\ \mathrm{INV}_{\mathrm{t}} & = & \text { inventory at time, } \\ \mathrm{AP}_{\mathrm{t}} & = & \text { accounts payable at time, }\end{array}$


Like Cheung et al. (1997), we scaled all variables by book value of total assets. Legoria and Sellers (2005) did not scale their operating cash flow variables. Also, the only control variables included in their model were sales, as a proxy for size, and operating cash flow from 1994.

\section{Statistical Method}

To test the predictive ability of deferred tax measures, several predictive models were developed. Three models were used to evaluate the incremental ability of deferred tax measures to predict future taxes paid:

(1) TAXPD $_{t+1}=\alpha_{0}+\alpha_{1} \operatorname{TAXPD}_{t}+\tau_{\mathrm{t}}$

(2) $\mathrm{TAXPD}_{\mathrm{t}+1}=\alpha_{0}+\alpha_{1} \mathrm{TAXPD}_{\mathrm{t}}+\alpha_{2} \mathrm{DEF} 1_{\mathrm{t}}+\rho_{\mathrm{t}}$

(3) $\mathrm{TAXPD}_{\mathrm{t}+1}=\alpha_{0}+\alpha_{1} \mathrm{TAXPD}_{\mathrm{t}}+\alpha_{2} \mathrm{DEF}_{\mathrm{t}}+\pi_{\mathrm{t}}$

The Vuong statistic ${ }^{1}$ was used to compare the predictive ability of the models. ${ }^{2}$ Thus, Comparison 1 (Model 2 vs. Model 1) tested the incremental predictive ability of DEF1 ${ }_{t}$ beyond TAXPD ${ }_{t}$ while Comparison 2 (Model 3 vs. Model 1) tested the incremental predictive ability of $\mathrm{DEF} 2_{\mathrm{t}}$ beyond $\mathrm{TAXPD}_{\mathrm{t}}$.

Six models were used to evaluate the incremental ability of deferred tax measures to predict future operating cash flows. Our base model included the variables from Cheung et al. (1997) listed above, as control variables. We then constructed three additional models by adding each of the different income tax expense measures separately to the base model. Another two models were constructed by adding taxes paid and one deferred tax measure at the same time to the base model. Thus, Model 4 included the base variables. Model 5 included the base variables and TAXPD. Model 6 included the base variables and $\mathrm{DEF}_{\mathrm{t}}$. Model 7 included the base variables and $\mathrm{DEF} 2_{\mathrm{t}}$. Model 8 and Model 9 were developed by adding the $\mathrm{DEF}_{\mathrm{t}}$ and $\mathrm{DEF}_{2}$, respectively, to Model 5.

Model 4 (base model): $\mathrm{CFFO}_{\mathrm{t}+1}=\alpha_{0}+\alpha_{1} \mathrm{CFFO}_{\mathrm{t}}+\alpha_{2} \mathrm{OIBDP}_{\mathrm{t}}+\alpha_{3} \mathrm{AR}_{\mathrm{t}}+\alpha_{4} \mathrm{INV}_{\mathrm{t}}+\alpha_{5} \mathrm{AP}_{\mathrm{t}}+\varepsilon_{\mathrm{t}}$

Model 5: $\mathrm{CFFO}_{\mathrm{t}+1}=\alpha_{0}+\alpha_{1} \mathrm{CFFO}_{\mathrm{t}}+\alpha_{2} \mathrm{OIBDP}_{\mathrm{t}}+\alpha_{3} \mathrm{AR}_{\mathrm{t}}+\alpha_{4} \mathrm{INV}_{\mathrm{t}}+\alpha_{5} \mathrm{AP}_{\mathrm{t}}+\alpha_{6} \mathrm{TAXPD}_{\mathrm{t}}+\eta_{\mathrm{t}}$

Model 6: $\mathrm{CFFO}_{\mathrm{t}+1}=\alpha_{0}+\alpha_{1} \mathrm{CFFO}_{\mathrm{t}}+\alpha_{2} \mathrm{OIBDP}_{\mathrm{t}}+\alpha_{3} \mathrm{AR}_{\mathrm{t}}+\alpha_{4} \mathrm{INV}_{\mathrm{t}}+\alpha_{5} \mathrm{AP}_{\mathrm{t}}+\alpha_{6} \mathrm{DEF}_{\mathrm{t}}+\gamma_{\mathrm{t}}$

Model 7: $\mathrm{CFFO}_{\mathrm{t}+1}=\alpha_{0}+\alpha_{1} \mathrm{CFFO}_{\mathrm{t}}+\alpha_{2} \mathrm{OIBDP}_{\mathrm{t}}+\alpha_{3} \mathrm{AR}_{\mathrm{t}}+\alpha_{4} \mathrm{INV}_{\mathrm{t}}+\alpha_{5} \mathrm{AP}_{\mathrm{t}}+\alpha_{6} \mathrm{DEF}_{\mathrm{t}}+\phi_{\mathrm{t}}$

Model 8: $\mathrm{CFFO}_{\mathrm{t}+1}=\alpha_{0}+\alpha_{1} \mathrm{CFFO}_{\mathrm{t}}+\alpha_{2} \mathrm{OIBDP}_{\mathrm{t}}+\alpha_{3} \mathrm{AR}_{\mathrm{t}}+\alpha_{4} \mathrm{INV}_{\mathrm{t}}+\alpha_{5} \mathrm{AP}_{\mathrm{t}}+\alpha_{6} \mathrm{TAXPD}_{\mathrm{t}}+\alpha_{7} \mathrm{DEF}_{\mathrm{t}}+\varphi_{\mathrm{t}}$

Model 9: $\mathrm{CFFO}_{\mathrm{t}+1}=\alpha_{0}+\alpha_{1} \mathrm{CFFO}_{\mathrm{t}}+\alpha_{2} \mathrm{OIBDP}_{\mathrm{t}}+\alpha_{3} \mathrm{AR}_{\mathrm{t}}+\alpha_{4} \mathrm{INV}_{\mathrm{t}}+\alpha_{5} \mathrm{AP}_{\mathrm{t}}+\alpha_{6} \mathrm{TAXPD}_{\mathrm{t}}+\alpha_{7} \mathrm{DEF}_{\mathrm{t}}+\kappa_{\mathrm{t}}$

The Vuong statistic was also used to compare the ability of these models to predict $\mathrm{CFFO}_{\mathrm{t}+1}$. Comparison 3 (Model 5 vs. Model 4), Comparison 4 (Model 6 vs. Model 4), and Comparison 5 (Model 7 vs. Model 4), tested the incremental predictive ability of TAXPD $\mathrm{TEF}_{\mathrm{t}}$, and $\mathrm{DEF} 2_{\mathrm{t}}$, respectively, beyond the control variables. Comparison 6 (Model 8 vs. Model 5) and Comparison 7 (Model 9 vs. Model 5) tested the incremental predictive ability of $\mathrm{DEF} 1_{\mathrm{t}}$ and $\mathrm{DEF} 2_{\mathrm{t}}$, respectively, beyond TAXPD.

\section{RESULTS}

\section{Descriptive Statistics}

Table 1 reports descriptive statistics for variables for the one-year-ahead $\mathrm{CFFO}_{\mathrm{t}+1}$ predictive model. Correlations (not reported) reveal that $T A X P D_{t+1}$ is positively correlated with $\mathrm{TAXPD}_{t}$, negatively correlated with $\mathrm{DEF} 1_{t}$, but not significantly

\footnotetext{
${ }^{1}$ The Vuong statistic has been used to compare the predictive ability of models in several studies of the information content of accounting information and disclosures. (For example, see Lougee and Marquardt, 2004; Moehrle et al., 2001; Barth, et al., 2001; and Dhaliwal et al., 1999.) We thank Donald Cram for making available the SAS code necessary to conduct Vuong tests.

${ }^{2}$ We thank Quang Vuong for his input into the proper use of the Vuong statistic in a nested model and his explanation of its superiority over other measures of incremental explanatory power. (See pp. 319-326 of Vuong, 1989.)
} 
correlated with $\mathrm{DEF} 2_{\mathrm{t}}$. $\mathrm{TAXPD}_{\mathrm{t}}$, is negatively correlated with $\mathrm{CFFO}_{\mathrm{t}+1}$ while $\mathrm{DEF} 1_{\mathrm{t}}$ and $\mathrm{DEF} 2_{\mathrm{t}}$ are positively correlated with $\mathrm{CFFO}_{\mathrm{t}+1}$. Thus, univariate correlations indicate potential usefulness of the deferred tax measures. Multivariate analysis examined the practical usefulness of the measures.

Table 1

Descriptive Statistics

Pooled Sample 1993-1999, N=31,620

\begin{tabular}{|c|c|c|c|c|c|}
\hline Variable & Mean & Median & Std Dev & Minimum & Maximum \\
\hline TAXPD $_{t+1}$ & 0.0216303 & 0.012419 & 0.062665 & -9.58096 & 0.774907 \\
\hline TAXPD $_{t}$ & 0.0226046 & 0.013311 & 0.065225 & -9.58096 & 2.730497 \\
\hline DEF1 $t_{t}$ & -0.0011609 & 0 & 0.032267 & -2.04149 & 2.417564 \\
\hline DEF2 $_{t}$ & 0.0016803 & 0 & 0.024958 & -2.28534 & 0.263574 \\
\hline CFFO $_{t+1}$ & 0.0307077 & 0.069056 & 0.59813 & -83.4954 & 20.72727 \\
\hline CFFOt $_{\text {t }}$ & 0.0372808 & 0.070374 & 0.631347 & -83.4954 & 8.01875 \\
\hline OIBDP $_{t}$ & 0.0821771 & 0.123194 & 0.548671 & -55.3571 & 1.984002 \\
\hline $\mathbf{A} \mathbf{R}_{\mathbf{t}}$ & 0.1911195 & 0.16998 & 0.14064 & 0 & 1 \\
\hline $\mathbf{I N V}_{\mathrm{t}}$ & 0.1517918 & 0.111572 & 0.158356 & 0 & 0.966725 \\
\hline $\mathbf{A} \mathbf{P}_{\mathbf{t}}$ & 0.1057424 & 0.074466 & 0.353205 & 0 & 43.33333 \\
\hline
\end{tabular}

TAXPD $_{t}=$ taxes paid during yeart.. DEF1 $1_{t}=$ deferred tax expense at time $t_{.}$DEF $2_{t}=$ change in the deferred tax liability from the balance sheet at time $_{t} . \mathrm{CFFO}_{\mathrm{t}}=$ cash flow from operating activities during yeart. $\mathrm{OIBDP}_{\mathrm{t}}=$ operating income before depreciation during yeart. $\mathrm{AR}_{\mathrm{t}}=\mathrm{accounts}_{\mathrm{s}}$ receivable at time $\mathrm{INV}_{\mathrm{t}}=$ inventory at time $\mathrm{AP}_{\mathrm{t}}=$ accounts payable at timet. All items are scaled by the book value of total assets at time .

\section{Regression Analysis}

We performed regression analysis using the models mentioned in the Statistical Methods section. Regressions with the taxes paid and deferred taxes variables for the full sample (32,173 observations) produced models with adjusted r-squares below 0.001. TAXPD ${ }_{t}$ was positive and significant at $\mathrm{p}<0.01$ in Models 1,2 , and 3 , while $\mathrm{DEF} 1_{\mathrm{t}}$ and $\mathrm{DEF} 2_{\mathrm{t}}$ were highly insignificant in Models 2 and 3, respectively. Regressions were also conducted for observations within each year, 1993 through 1999 (number of observations varying from 4,275 to 4,771). The adjusted r-squares for these models never exceeded 0.011 . TAXPD $_{t}$ was positive and significant at $p<0.01$ in models from 1993 to 1997 observations, but was insignificant for 1998 and 1999 observations. $\mathrm{DEF}_{\mathrm{t}}$ was insignificant for all years except 1996, when it was positive and slightly significant at $\mathrm{p}<0.10$. $\mathrm{DEF} 2 \mathrm{t}$ was negative and significant for 1995 observations while positive and significant for 1999 observations. (Results are available upon request from the authors.)

Table 2 reports the regression results from the $\mathrm{CFFO}_{t+1}$ predictive models for the total sample and within-year samples. ${ }^{3}$ TAXPD $\mathrm{t}_{\mathrm{t}}$ was insignificant for the regression including all observations, but positive and significant at $\mathrm{p}<0.01$ in regressions with 1994 and 1996 observations. $\mathrm{DEF}_{\mathrm{t}}$ was positive and significant at $\mathrm{p}<0.01$ for the regression including all observations, but insignificant for all years except 1998, when it was positive and significant at $\mathrm{p}<0.01$. DEF2 $\mathrm{t}_{\mathrm{t}}$ was insignificant for the regression including all observations, but positive and significant at $p<0.01$ regressions with 1998 and 1999 observations.

The regression results were mixed as to the significance and signs of the deferred tax variables. $D E F 1_{t}$ and $D E F 2_{t}$ appear to possess no predictive value related to one-year-ahead tax payments and mixed results regarding predictive value for

\footnotetext{
${ }^{3} \mathrm{CFFO}_{\mathrm{t}}$ and OIBDP $\mathrm{t}$ are highly correlated (at 0.89 ). Consequently, the parameter estimates and significance tests on those two variables must be interpreted carefully when both are included in an OLS regression model. However, the Vuong statistic is an appropriate test of incremental explanatory power even when the initial model is misspecified.
} 
one-year-ahead operating cash flows.

Table 2

Regression Results

\begin{tabular}{|c|c|c|c|c|c|c|c|c|}
\hline Variables & $\begin{array}{l}\text { All Cos., } \\
\text { all years } \\
\text { and } \\
\text { industries }\end{array}$ & $\begin{array}{l}\text { All Cos. } \\
\text { and } \\
\text { industries } \\
1993\end{array}$ & $\begin{array}{l}\text { All Cos. } \\
\text { and } \\
\text { industries } \\
1994\end{array}$ & $\begin{array}{l}\text { All Cos. } \\
\text { and } \\
\text { industries } \\
1995\end{array}$ & $\begin{array}{l}\text { All Cos. } \\
\text { and } \\
\text { industries } \\
1996\end{array}$ & $\begin{array}{c}\text { All Cos. } \\
\text { and } \\
\text { industries } \\
1997\end{array}$ & $\begin{array}{c}\text { All Cos. } \\
\text { and } \\
\text { industries } \\
1998\end{array}$ & $\begin{array}{c}\text { All Cos. } \\
\text { and } \\
\text { industries } \\
1999\end{array}$ \\
\hline Intercept & $0.023 * * *$ & $-0.226 * * *$ & $0.234 * * *$ & $-0.057 * * *$ & $-0.012 * *$ & $-0.056 * * *$ & 0.011 & 0.001 \\
\hline (t-statistic) & 3.80 & -7.73 & $6.45 * * *$ & $-6.639 * * *$ & $-2.11 * *$ & $-4.59 * * *$ & 1.55 & 0.07 \\
\hline CFFOt $_{\mathrm{t}}$ & $-0.404 * * *$ & $-1.668 * * *$ & $-0.164 * * *$ & $0.060 * *$ & $0.240 * * *$ & $0.318 * * *$ & $-0.076 * * *$ & $-0.243 * * *$ \\
\hline (t-statistic) & -37.39 & $-16.20 * * *$ & -18.45 & $1.99 * *$ & $10.44 * * *$ & $6.34 * * *$ & $-5.12 * * *$ & $-9.58 * * *$ \\
\hline OIBDEP $_{t}$ & $0.764 * * *$ & $3.891 * * *$ & $0.558 * * *$ & $0.0850 * * *$ & $0.396 * * *$ & $0.566 * * *$ & $0.311 * * *$ & $0.376 * * *$ \\
\hline (t-statistic) & 59.71 & $58.53 * * *$ & $25.73 * * *$ & 32.04 & $18.30 * * *$ & 13.90 & $26.51 * * *$ & $15.19 * * *$ \\
\hline $\mathbf{A} \mathbf{R}_{\mathbf{t}}$ & $-0.128 * * *$ & $-0.973 * * *$ & $-0.085 * * *$ & -0.050 & $-0.039 *$ & $0.082 *$ & 0.019 & 0.075 \\
\hline (t-statistic) & -5.76 & $-9.06^{* * *}$ & $-4.37 * * *$ & -1.50 & $-1.85^{*}$ & $1.179 *$ & 0.68 & 1.30 \\
\hline INV $_{t}$ & $-0.051 * * *$ & $-0.380 * * *$ & $-0.201 * * *$ & $-0.083 * * *$ & $-0.045^{* *}$ & 0.040 & $-0.058 * *$ & 0.082 \\
\hline (t-statistic) & -2.60 & $-4.02 * * *$ & $11.83 * * *$ & $-2.89 * * *$ & -2.43 & 0.99 & $-2.35 * *$ & 1.59 \\
\hline $\mathbf{A} \mathbf{P}_{\mathbf{t}}$ & $-0.069 * * *$ & $2.145^{* * *}$ & $0.176^{* * *}$ & $0.350 * * *$ & $0.152 * * *$ & $-0.103 *$ & $0.083 * * *$ & $-0.294 * * *$ \\
\hline (t-statistic) & -7.05 & $13.47 * * *$ & $11.60 * * *$ & 13.77 & 5.05 & $-1.73 *$ & $3.15 * * *$ & $-21.79 * * *$ \\
\hline \multicolumn{9}{|l|}{$\begin{array}{l}\text { Added } \\
\text { Variables }^{1}\end{array}$} \\
\hline TAXPD $_{t}$ & 0.000 & -0.000 & $0.000 * * *$ & 0.000 & $0.000 * *$ & 0.000 & $0.000 * * *$ & 0.000 \\
\hline (t-statistic) & 0.87 & -1.46 & $3.20 * * *$ & 0.41 & $2.55 * *$ & 0.50 & $3.20 * * *$ & 0.29 \\
\hline DEF1 $_{t}$ & $0.313 * * *$ & 1.100 & -0.040 & -0.117 & 0.051 & 0.305 & $0.609 * * *$ & 0.008 \\
\hline (t-statistic) & 2.96 & 1.29 & -0.27 & -0.60 & 0.44 & 1.33 & $7.79 * * *$ & 0.04 \\
\hline DEF 2 $t$ & 0.124 & -0.162 & -0.100 & -0.178 & 0.152 & 0.199 & $0.642 * * *$ & $-0.809 * * *$ \\
\hline (t-statistic) & 1.53 & -0.24 & -0.63 & -0.65 & 0.73 & 0.60 & $8.23 * * *$ & $-2.34 * * *$ \\
\hline Range of & $0.1537-$ & $0.495-$ & $40.85-$ & $31.88-$ & $0.326-$ & $18.84-$ & 0.4038 & $0.2196-$ \\
\hline $\begin{array}{l}\text { No. of } \\
\text { observations }\end{array}$ & 32,620 & 4,205 & 4,416 & 4,593 & 4,940 & 4,694 & 4,422 & 4,350 \\
\hline
\end{tabular}

* significant at $10 \%$ level; $* *$ significant at $5 \%$ level; $* * *$ significant at $1 \%$ level

${ }^{1}$ The coefficient estimates and $\mathrm{t}$-statistics for the control variables are from the base model. The coefficient estimates and t-statistics for variables of interest are from models in which TAXPD,$D E F 1_{t}$, and DEF $2_{t}$ were added individually to the base model. The coefficient estimates and t-statistics on all the variables changed little when one or two of the variables of interest were included in the same model.

See Table 1 for a description of the variables.

\section{Vuong Statistics For Comparisons Of Models}

As we mentioned in the Extensions of Previous Research section, we initially followed Cheung et al. (1997) and used the Mean Absolute Percentage Error (MAPE) of the models' predictions and the Friedman's S statistic to compare the models. However, the MAPEs were contradictory and inconsistent with the regression results. Consequently, we performed comparisons of the models' predictive accuracy by calculating and evaluating a Vuong statistic for the comparisons.

Table 3 reports the results from Vuong statistics for comparisons of the TAXPD ${ }_{t+1}$ and $\mathrm{CFFO}_{t+1}$ predictive models for the pooled sample and for each yearly sub sample of data. The Vuong statistics indicate that no predictive models that include 
$\mathrm{DEF}_{\mathrm{t}}$ or $\mathrm{DEF} 2 \mathrm{t}_{\mathrm{t}}$ are significantly better than models that do not include a deferred tax measure, contrary to results obtained by Cheung, et al. (1997) and Krishnan and Largay (2000). As we discussed earlier, our use of a more appropriate sample period and more powerful statistical methods may explain the difference.

Table 3

Summary of Results of Vuong Statistics Analyses Comparing Predictive Power of Models Without Deferred Tax Measures to Models with Deferred Tax Measures (Pooled Sample and Yearly Sample)

\begin{tabular}{|c|c|c|c|}
\hline & $\mathbf{N}$ & $\begin{array}{c}\text { Comparisons with } \\
\text { Significant Vuong } \\
\text { Statistics } \\
\end{array}$ & $\begin{array}{c}\text { Sign on Coefficient in } \\
\text { Original Regression }\end{array}$ \\
\hline \multicolumn{4}{|l|}{ Complete Sample } \\
\hline Predict Taxes Paid t+1 (Comparisons 1 and 2) & 32,173 & None & \\
\hline Predict CFFO $\mathrm{t}+1$ (Comparisons 3-7) & 31,620 & None & \\
\hline \multicolumn{4}{|l|}{1993 Base year } \\
\hline Predict Taxes Paid 1994 (Comparisons 1 and 2) & 4,275 & None & \\
\hline Predict CFFO 1994 (Comparisons 3-7) & 4,203 & None & \\
\hline \multicolumn{4}{|l|}{1994 Base year } \\
\hline Predict Taxes Paid 1995 (Comparisons 1 and 2) & 4,499 & None & \\
\hline Predict CFFO 1995 (Comparisons 3-7) & 4,416 & Comp. 3* & + TAXPD \\
\hline \multicolumn{4}{|l|}{1995 Base year } \\
\hline Predict Taxes Paid 1996 (Comparisons 1 and 2) & 4,690 & None & \\
\hline Predict CFFO 1996 (Comparisons 3-7) & 4,594 & None & \\
\hline \multicolumn{4}{|l|}{1996 Base year } \\
\hline Predict Taxes Paid 1997 (Comparisons 1 and 2) & 5,028 & None & \\
\hline Predict CFFO 19997 (Comparisons 3-7) & 4,941 & None & \\
\hline \multicolumn{4}{|l|}{1997 Base year } \\
\hline Predict Taxes Paid 1998 (Comparisons 1 and 2) & 4,771 & None & \\
\hline Predict CFFO 1998 (Comparisons 3-7) & 4,694 & None & \\
\hline \multicolumn{4}{|l|}{1998 Base year } \\
\hline Predict Taxes Paid 1999 (Comparisons 1 and 2) & 4,487 & None & \\
\hline Predict CFFO 1999 (Comparisons 3-7) & 4,422 & Comp. 3* & + TAXPD $_{t}$ \\
\hline \multicolumn{4}{|l|}{1999 Base year } \\
\hline Predict Taxes Paid 2000 (Comparisons 1 and 2) & 4,422 & None & \\
\hline Predict CFFO 2000 (Comparisons 3-7) & 4,350 & None & \\
\hline
\end{tabular}

Comparison 1: Model $1 \mathrm{v}$. Model 2, TAXPD $\mathrm{t}_{+1}=\left(\mathrm{TAXPD}_{\mathrm{t}} \mathrm{v} . \mathrm{TAXPD}_{\mathrm{t}}+\mathrm{DEF}_{\mathrm{t}}\right)$

Comparison 2: Model $1 \mathrm{v}$. Model 3, TAXPD $t+1=\left(\right.$ TAXPD $_{t}$ v. TAXPD $t+$ DEF2 $\left._{t}\right)$

For Comparisons 3-7: Pred $\mathrm{CFFO}_{t+1}, \mathrm{~B}_{\mathrm{t}}=$ base model $=\mathrm{CFFO}_{t}+\mathrm{OIBDPP}_{\mathrm{t}}+\mathrm{REC}_{\mathrm{t}}+\mathrm{INVTY}_{\mathrm{t}}+\mathrm{APAY}_{\mathrm{t}}$

Comparison 3: Pred CFFO $\mathrm{t}_{+1}\left(\mathrm{~B}_{\mathrm{t}} \mathrm{v} . \mathrm{B}_{\mathrm{t}}+\mathrm{TAXPD}_{\mathrm{t}}\right)$

Comparison 4: Pred CFFO $\mathrm{t}_{\mathrm{t}+1}\left(\mathrm{~B}_{\mathrm{t}} \mathrm{v} . \mathrm{B}_{\mathrm{t}}+\mathrm{DEF}_{\mathrm{t}}\right)$

Comparison 5: Pred CFFO $\mathrm{t}_{t+1}\left(\mathrm{~B}_{\mathrm{t}} \mathrm{v} . \mathrm{B}_{\mathrm{t}}+\mathrm{DEF}_{\mathrm{t}}\right)$

Comparison 6: Pred CFFO ${ }_{t+1}\left(\mathrm{~B}_{t}+\right.$ TAXPD $_{t} v$. $\mathrm{B}_{t}+$ TAXPD $\left._{t}+\mathrm{DEF}_{\mathrm{t}}\right)$

Comparison 7: Pred CFFO ${ }_{t+1}\left(B_{t}+\right.$ TAXPD $_{t} v . B_{t}+$ TAXPD $\left._{t}+\mathrm{DEF}_{\mathrm{t}}\right)$

* Comparison was significant @ $\mathrm{p} \leq .10$.

See Table 1 for a description of the variables. 
Like Cheung, et al. (1997), we conducted analysis on sub samples of companies within two-digit SIC codes; only sub samples that contained 50 or more observations were included in the analyses. Table 4 summarizes the results of Vuong statistics for comparisons of models from regression analysis of data from companies within the same two-digit SIC codes using the pooled sample of years 1993 to 2000. Considering the large number of comparisons conducted, results reported in Table 4 provide little evidence that deferred tax information is useful in predicting taxes paid or cash flow from operations one year in the future. The number of significant comparisons within SIC codes is not greater than that expected by chance.

Table 4

Summary of Results of Vuong Statistics Analyses Comparing Predictive Power of Models Without Deferred Tax Measures to Models with Deferred Tax Measures (Within Two-Digit SIC Codes Within Pooled Sample)

\begin{tabular}{|c|c|c|c|}
\hline All Base Years, Comparisons within Two-digit SIC (Obs. > 50) & $\begin{array}{c}\text { Number of } \\
\text { Comparisons } \\
\text { (Industries) }\end{array}$ & $\begin{array}{c}\text { Number of } \\
\text { Significant } \\
\text { Vuong } \\
\text { Statistics } \\
\end{array}$ & $\begin{array}{c}\text { Sign on } \\
\text { Coefficient in } \\
\text { Original } \\
\text { Regression } \\
\end{array}$ \\
\hline \multicolumn{4}{|l|}{ Predict Taxes Paid $\mathrm{t}+1$} \\
\hline $\begin{array}{l}\text { Comparison 1: Model } 1 \text { v. Model 2, } \\
\text { TAXPD }_{t+1}=\left(\text { TAXPD }_{t} \text { v. TAXPD }\right. \\
\text { TAEF1 })\end{array}$ & 54 & $1 @ \mathrm{p} \leq 0.10$ & $+\mathrm{DEF} 1_{\mathrm{t}}$ \\
\hline \multirow[t]{2}{*}{$\begin{array}{l}\text { Comparison 2: Model } 1 \text { v. Model 3, } \\
\text { TAXPD }_{t+1}=\left(\text { TAXPD }_{t} \text { v. TAXPD }\right. \\
\text { TAEF2 }\end{array}$} & 54 & $4 @ \mathrm{p} \leq 0.10$ & $+\mathrm{DEF} 2 \mathrm{t}$ \\
\hline & & $1 @ \mathrm{p} \leq 0.05$ & $+\mathrm{DEF} 2 \mathrm{t}$ \\
\hline \multicolumn{4}{|l|}{$\begin{aligned}{\text { Pred } \mathrm{CFFO}_{\mathrm{t}+1}, \mathrm{~B}_{\mathrm{t}}} & \text { base model } \\
& =\mathrm{CFFO}_{\mathrm{t}}+\mathrm{OIBDPP}_{\mathrm{t}}+\mathrm{REC}_{\mathrm{t}}+\mathrm{INVTY}_{\mathrm{t}}+\mathrm{APAY}_{\mathrm{t}}\end{aligned}$} \\
\hline \multirow[t]{3}{*}{ Comparison 3: Pred $\mathrm{CFFO}_{\mathrm{t}+1}\left(\mathrm{~B}_{\mathrm{t}} \mathrm{v} . \mathrm{B}_{\mathrm{t}}+\mathrm{TAXPD}_{\mathrm{t}}\right)$} & 54 & $1 @ \mathrm{p} \leq 0.10$ & + TAXPD $_{t}$ \\
\hline & & $3 @ p \leq 0.10$ & - TAXPD \\
\hline & & $1 @ \mathrm{p} \leq 0.05$ & + TAXPD \\
\hline Comparison 4: Pred $\mathrm{CFFO}_{\mathrm{t}+1}\left(\mathrm{~B}_{\mathrm{t}} \mathrm{v} . \mathrm{B}_{\mathrm{t}}+\mathrm{DEF}_{\mathrm{t}}\right)$ & 54 & $1 @ p \leq 0.10$ & $-\mathrm{DEF} 1_{\mathrm{t}}$ \\
\hline \multirow[t]{2}{*}{ Comparison 5: Pred $\mathrm{CFFO}_{\mathrm{t}+1}\left(\mathrm{~B}_{\mathrm{t}} \mathrm{v} . \mathrm{B}_{\mathrm{t}}+\mathrm{DEF}_{\mathrm{t}}\right)$} & 54 & $2 @ p \leq 0.10$ & $-\mathrm{DEF} 2_{\mathrm{t}}$ \\
\hline & & $1 @ p \leq 0.05$ & $-\mathrm{DEF} 2 \mathrm{t}$ \\
\hline Comparison 6: Pred CFFO ${ }_{t+1}\left(B_{t}+\right.$ TAXPD $_{t} v \cdot B_{t}+$ TAXPD $_{t}+$ DEF1 $\left._{t}\right)$ & 54 & $1 @ \mathrm{p} \leq 0.10$ & - DEF1t \\
\hline \multirow{2}{*}{ Comparison 7: Pred CFFO ${ }_{t+1}\left(B_{t}+\right.$ TAXPD $_{t} v \cdot B_{t}+$ TAXPD $_{t}+$ DEF$\left._{t}\right)$} & 54 & $2 @ p \leq 0.10$ & $-\mathrm{DEF}_{\mathrm{t}}$ \\
\hline & & $1 @ p \leq 0.05$ & $-\mathrm{DEF} 2_{\mathrm{t}}$ \\
\hline
\end{tabular}

See Table 1 for a description of the variables.

\section{Additional Analyses}

We also conducted Vuong comparisons of models produced using data from companies within two-digit SIC codes within each individual year of the sample period (not reported). These results did not reveal more significant comparisons than expected by chance. Also in this analysis, the deferred tax variables' coefficients are sometimes positive and sometimes 
negative in the significantly superior prediction models of both taxes paid and cash flow from operations.

Like Cheung et al. (1997), we also conducted an analysis similar to that reported in Tables 3 and 4 with data only from companies that had a deferred tax liability greater than $1 \%$ of their total assets. This analysis should capture data from companies for which deferred tax information should be most relevant to future cash flow predictive models. This criterion resulted in 13,043 observations for the tax paid predictions models and 12,770 observations for the operating cash flow predictions models.

Results (not reported) with the pooled sample and each year's total sample produced no significant difference between the models, and consequently, no evidence that deferred tax measures provide any useful information in predicting taxes paid or cash flow from operations one year in the future. Analysis within SIC codes may provide some weak evidence that deferred tax measures might provide useful information. For the 44 TAXPD $_{t+1}$ prediction models, the Vuong analysis by SIC code sub sample across years did not produce any more significant comparisons than expected by chance. However, the 43 comparisons of a cash flow from operations prediction model including TAXPD ${ }_{t}$ vs. a model including $\mathrm{TAXPD}_{\mathrm{t}}$ and $\mathrm{DEF}_{\mathrm{t}}\left(\mathrm{Comparison}_{\mathrm{t}}\right.$ ) exhibited slightly more significant Vuong statistics than expected by chance. Also, the sign on the $\mathrm{DEF} \mathrm{t}_{\mathrm{t}}$ coefficient was consistently negative in the models that produced significant Vuong statistics.

The within reporting year and SIC code sub samples resulted in 71 and 70 comparisons for the TAXPD ${ }_{t+1}$ and $\mathrm{CFFO}_{\mathrm{t}+1}$ prediction models, respectively. Comparisons 1 and 2 each produced 2 Vuong statistics significant at $\mathrm{p} \leq 0.01$, slightly more than would be expected by chance. However, the signs on the $\mathrm{DEF} 1_{\mathrm{t}}$ and $\mathrm{DEF}{ }_{\mathrm{t}}$ parameter estimates were not consistently positive or negative in the resulting regression equations. Of the 70 comparisons for the $\mathrm{CFFO}_{\mathrm{t}+1}$ prediction models that included $\mathrm{DEF} 1_{\mathrm{t}}$ and $\mathrm{DEF} 2_{\mathrm{t}}$, respectively, the number of significant Comparisons 6 and 7 is not as high as the number expected by chance. Also, the sign of the coefficients on $\mathrm{DEF} 1_{\mathrm{t}}$ and $\mathrm{DEF}{ }_{\mathrm{t}}$ are not consistent across the sub samples analyzed.

To determine whether decreases or increases in the total deferred tax liability $\left(\mathrm{DEF}_{\mathrm{t}}\right)$ provided differing useful information, we segregated companies into one sample that only included companies with positive $\mathrm{DEF} 1_{\mathrm{t}}(13,311$ observations) and another sample that included only companies with negative $\mathrm{DEF}_{\mathrm{t}}(13,030$ observations). We then conducted the same analysis as described above for our other samples. (Results not reported.) Results for these analyses were similar to results discussed above.

Our analyses (reported in tables and not reported) generally produced mixed results, and at most, very weak evidence of the usefulness of deferred tax measures reported in the financial statements. The varying results across time and industries lead us to question the practical usefulness of deferred tax measures in predicting future taxes paid and cash flow from operations. Consequently, we do not believe we have sufficient evidence to reject $\mathrm{H}_{1}$ that states that deferred tax measures do not improve the predictive accuracy of one-year-ahead taxes paid prediction models or $\mathrm{H}_{2}$ that states that deferred tax measures do not improve the predictive accuracy of one-year-ahead operating cash flow prediction models.

\section{CONCLUSIONS}

We extend previous research related to deferred income tax information by limiting our sample to a timeframe covered by SFAS No. 109. This allows us to test the usefulness of items currently reported in the financial statements and to obtain our cash flow information currently reported on the cash flow statement. Many prior studies used estimated cash flow information based on income statement and balance sheet items. Research by Bahnson et al. (1996) has shown that significant differences exist between cash flows reported on the cash flow statement and those estimated from information on the other financial statements. In addition, our inclusion of a taxes paid variable in our operating cash flow prediction models, and use the Vuong statistic, provide a better test of the incremental usefulness of deferred tax information.

Our results provide very little evidence that deferred tax measures (DEF1 and DEF2) possess usefulness in predicting one-year-ahead taxes paid or cash flow from operations when added to models that include taxes paid (TAXPD). These results conflict with those obtained by Cheung, et al. (1997) and Krishnan and Largay (2000). 
Differences in sampling techniques, variable selection, and statistical measures used in this study may explain the differing results.

Our study results do not suggest that deferred tax information satisfies the decision usefulness criteria set out by the FASB for reporting standards when used to predict one-year-ahead cash flows. However, a limiting aspect of our study was that we examined only the deferred tax information reported in the financial statements. We did not examine the usefulness of companies' deferred tax assets, valuation allowances, and deferred tax liabilities disclosed in footnotes as did Legoria and Sellers (2005). As information becomes more readily available, analysis of a broader time period incorporating deferred tax assets, valuation allowances, and deferred tax liabilities should be pursued. Also, to fully address the propriety of requiring interperiod tax allocation, future research, in different user contexts, should include taxes paid as a control variable in predictive and valuation models examining the usefulness of deferred tax information.

\section{REFERENCES}

1. Accounting Principles Board (1967), A.P.B. Opinion No. 11, Accounting for Income Taxes.

2. American Accounting Association (1977), Statement of Accounting Theory and Theory Acceptance (Sarasota, FL: American Accounting Association).

3. Aziz, A. and Lawson G. H. (1989), Cash flow reporting and financial distress models: testing of hypotheses, Financial Management, Vol. 18, (1), Spring, pp. 55-63.

4. Barth, M. E., Cram, D. P., and Nelson, K. K. (2001), Accruals and the prediction of future cash flows, The Accounting Review, Vol. 76, (1), January, pp. 27-58.

5. Bahnson, P. R., Miller, P., and Budge, B. (1996). Nonarticulation in cash-flow statements and implications for education, research, and practice, Accounting Horizons, Vol. 10, December, pp. 1-15.

6. Cheung, J. K., Krishnan, G. V., and Min, C. (1997), Does interperiod income tax allocation enhanced prediction of cash flows?, Accounting Horizons, Vol. 11, (4), December, pp. 1-15.

7. Financial Accounting Standards Board (1978), Statement of Financial Accounting Concepts No. 1: Objectives of Financial Reporting by Business Enterprises (New York: Financial Accounting Standards Board).

8. Financial Accounting Standards Board (1980), Statement of Financial Accounting Concepts No. 2: Qualitative Characteristics of Accounting Information (New York: Financial Accounting Standards Board).

9. Financial Accounting Standards Board (1987a), Statement of Financial Accounting Standards No. 95: Statement of Cash Flows (New York: Financial Accounting Standards Board).

10. Financial Accounting Standards Board (1987b), Statement of Financial Accounting Standards No. 96: Accounting for Income Taxes (New York: Financial Accounting Standards Board).

11. Financial Accounting Standards Board (1992), Statement of Financial Accounting Standards No. 109: Accounting for Income Taxes (New York: Financial Accounting Standards Board).

12. Heath, L. C. (1978), Financial Reporting and the Evaluation of Solvency. (New York: American Institute of Certified Public Accountants).

13. Krishnan, G. V. and Largay III, J. A. (2000), The predictive ability of direct method cash flow information, Journal of Business Finance \& Accounting, Vol. 27, (1 \& 2), January/March, pp. 215-245.

14. Lee, T. A. (1972), A case for cash flow reporting, Journal of Business Finance, Vol. 4, (2), Summer, pp. $27-36$.

15. Legoria, J. and Sellers, K. F. (2005), The analysis of SFAS No. 109's usefulness in predicting future cash flows from a conceptual framework perspective, Research in Accounting Regulation, Vol. 18, pp. 143-161.

16. Lorek, K. S. and Willinger, G. L. (1996), A multivariate time-series prediction model for cash flow data, The Accounting Review, Vol. 71, January, pp. 81-101.

17. Thomas, A. L. (1969), The allocation problem in financial accounting theory. Studies in Accounting Research No. 3 (Sarasota, FL: American Accounting Association).

18. Thomas, A. L. (1974), The allocation problem: part two. Studies in Accounting Research No. 9 (Sarasota, FL: American Accounting Association).

19. Thomas, A. L. (1975). The FASB and the allocation fallacy, Journal of Accountancy, Vol. 140, (5), November, pp. 65-68. 
20. Vuong, Q. (1989), Likelihood Ratio Test for Model Selection and Non-Nested Hypotheses, Econometrica Vol. 57 (2), pp. 307-333.

21. Ward, T. J. (1995), Using information from the statement of cash flows to predict firm Insolvency, The Journal of Commercial Lending, Vol. 77, (7), March, pp. 29-36.

22. Ward, T. J. and Foster, B. P. (1996), An empirical analysis of Thomas's financial accounting allocation fallacy theory in a financial distress context, Accounting and Business Research, Vol. 26, (2), Spring, pp. 137-152.

\begin{tabular}{|c|c|c|}
\hline \multicolumn{3}{|c|}{ APPENDIX } \\
\hline \multicolumn{3}{|c|}{ Sample Distributions for Taxes Paid Predictions } \\
\hline \multicolumn{3}{|c|}{ Panel A: Distribution of Observations by 1-digit SIC Code } \\
\hline 11-Digit Code & Frequency & Percent of Total Sample \\
\hline 0 & 139 & 0.43 \\
\hline 1 & 1,873 & 5.83 \\
\hline 2 & 4,878 & 15.17 \\
\hline 3 & 10,454 & 32.48 \\
\hline 4 & 3,992 & 12.41 \\
\hline 5 & 4,296 & 13.36 \\
\hline 7 & 4,764 & 14.82 \\
\hline 8 & 1,579 & 4.91 \\
\hline 9 & 198 & 0.62 \\
\hline Totals & $\mathbf{3 2 , 1 7 3}$ & $\underline{100}$ \\
\hline \multicolumn{3}{|c|}{ Panel B: Distribution of Observations by Year } \\
\hline Year & Frequency & Percent of Total Sample \\
\hline$\overline{1993}$ & 4,275 & 13.29 \\
\hline 1994 & 4,499 & 13.98 \\
\hline 1995 & 4,691 & 14.58 \\
\hline 1996 & 5,028 & 15.63 \\
\hline 1997 & 4,771 & 14.83 \\
\hline 1998 & 4,487 & 13.95 \\
\hline 1999 & $\underline{4,422}$ & 13.74 \\
\hline Totals & 32,173 & $\underline{\underline{100}}$ \\
\hline
\end{tabular}

